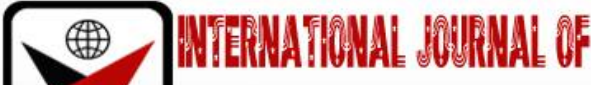

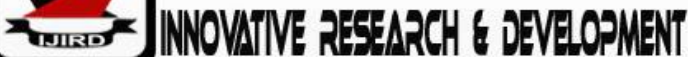

ISSN 2278-0211 (Online)

\section{The Effect of Financial Control System on Performance of Banks in Rwanda}

\author{
Celestin Karera \\ MBA Student, Department of Finance, School of Business Studies, \\ Jomo Kenyatta University, Kenya \\ Dr. Patrick Mulyungi \\ Lecturer, School of Business Studies, Jomo Kenyatta University, Kenya
}

\begin{abstract}
:
This study investigated the effect of the financial control system on the performance of commercial banks in Rwanda. A survey using a questionnaire was conducted on two hundred and forty (240) employees drawn from fourteen commercial Banks. The focus was on employees from departments that deal with financial control systems within the banking sectors visa vis Corporate Business Banking, Retail Business Banking, Financial Control, Internal Audit, Operations, and Credit Risk. Descriptive and correlation statistics were computed from the data obtained. The findings of the study indicated that the role of Finance Control teams in Formulation and Management of the Bank Performance Standards had a mean $(\bar{X}=2.69)$, and a standard deviation of $(S=0.32)$, Management of flows of Resources has got a mean $(\bar{X}=2.93)$, and a standard deviation of $(S=0.23) ;$ while the Prevention and management of operational Risk gets a mean $(\bar{X}=3.45)$, and a standard deviation of $(S=0.31)$. Further Statistical evidence depict that there is a significant relationship between, Formulation and Management of the Bank Performance Standards $p=.150$ and sig $=0.021$ (sig<0.05), Management of flows of Resources $p=.217$ and sig $=0.001$ (sig<0.05), the Prevention and management of operational Risk $p=.061$ and sig $=0.768$ (sig $>0.05$ ). ; It was concluded that banks that carry out Financial Control activities on a regular basis have got a good performance, considering the financial control as an integral part of the management functions it influences the performance of commercial Banks. In line with findings it is recommended that banks adopt elaborate financial control systems in tandem with central bank regulations to effectively improve on the sectors performance and overall economy of Rwanda.
\end{abstract}

Keywords: Financial control, return on equity, cost effectiveness, liquidity, capital adequacy and leverage

\section{Background}

Financial control is defined as the procedures designed to protect assets and insure that all financial transactions are recorded to prevent and reduce errors and fraud (Block\& Geoffrey, 2008).The goal of having a strong system of financial control is to promote the institution's ability to reach its objective, providing reliable financial data, safeguard assets and records, evaluating operational efficiency through budget, organizational control and encouraging adherence to prescribed policies and regulations (Wachira, et al, 2014). Financial Control is an integral part of the Financial Management the later deals with planning, organizing directing and controlling the financial activities in a firm (Daniel Mulinge Nthenge, 2017)

Eduard Alexandrovich Osadchy, (2015), through his study "The development of Financial Control System in the Company in crisis in Russian" defined Financial control as a system of observation, inspection, evaluation and correction of the situation on the basis of developed criteria (indicators), He further suggests that financial control should be implemented primarily in interest of the organization, its owners and the employees, it is important for the manager to know the dynamics of situational changes to be able to join the management of the workflow from the top in time of repeated failures or warn employees about the impending threat of collapse. Management control involves the joint from Top and bottom elimination of random negative situations that constantly arise in the work. Precisely He asserts that Financial Control is a management function that allows to quickly identify and eliminate conditions and factors that are not conducive to efficient administration and achievement of the goals; it makes it possible to determine what services and parts of the organization and activities contribute to the efficient achievement of the goals.

The same study asserts that an effective Financial Control System allows the management to delegate powers over cost management to subordinates who in fact can know the facts in details. Financial Control plays a significant role to the decision making of any organization as it manages flow of resources, monitors the use of these resources, participate in formulation of performance standards, Controls the performances standards, track the deviations of the performance 
standards, makes and discuss the reasons behind the deviations and recommends some corrective measures as a tool to management decision.

On Rwanda based cases, we observed a shortage of literature analyzing the role of Financial Control System on performance and stability of the organizations in general and the banks in particular, therefore we think that Financial Control System was not given its significance in the matter, yet we believe that a well-designed and properly functioning Financial Control System can play a significant role on the performance of the banks by being an effective tool to the management decisions; it is in that spirit that this study was conducted. - The following banks have got operating license in Rwanda (Bank of Kigali, KCB Bank Rwanda, I\& M Bank Rwanda, Cogebanque, Equity Bank Rwanda limited, Eco bank Rwanda, BPR-Atlass Mara, Access Bank Rwanda, NCBA Bank Rwanda PLC, Bank of Africa, Guaranty Trust Bank, Urwego Opportunity Bank, Unguka Bank and AB Bank).

\section{Literature Review}

\subsection{Financial Control Theory}

According to Financial Control theory, Personal Functions of a human being are asserted to constitute the fundamental point of reference, The theory stipulates that existing and possible functions of financial tools for organizations are most essential; it further states that, Payments, Financial instruments, accounting, control models, economic calculations and related considerations both within and outside the organization, ought to be discussed in regard to inner characteristics but also possible effect. It is noted that establishing the relationship between various activities and financial process from a financial control point of view is a general and basic issue (Ostman, 2009). The theory of financial controls for organizations places a natural focus on the firms such that they are viewed from several latitudinal areas the first area regards the human being's function of what is accomplished through organizations, their activities and outputs.

The second area concerns the organizational structure and activities, as well as transactions between parties in the organization. Third area covers the control systems in the sense of recurring procedures and methods being employed in order to relate present and future functions to resources. The financial control tools were argued to be important for both individual companies and large economic systems. The fourth area of the theory regards specific processes of individual organizations for certain issues. The financial theory states that structure and financial control system works together (Joshi et al, 2003). This theory is relevant to our study given that it assisted to better understand the details surrounding financial control system in commercial banks.

\subsection{Performance Theory}

According to Sabine S. \& Michael (2017), Perceived relationships between different performance dimensions are referred to as performance theory. According to the theory choosing a dimension of performance as a basis for reward, staffing, or development decisions implies that it is important for an organization because it affects its current and future performance, more often performance theory exist in the minds of individuals through the organization-Consciously or unconsciously they evolve over time as the individuals observe performance and its effects throughout their careers, and they provide structure whenever these individuals assess performance, formally or informally .

Researchers adopted three perspective for studying Performance (1) i.e. an individual differences perspective concerned with individual characteristics (One's Mental ability, Personality, etc.), as sources justifying variations between Performances. (2) A situational Perspective which focuses on situational aspects as facilitators and impediments for Performance. (3) Performance Regulation Perspective which describes the performance process. The three perspectives are not mutually exclusive but they approach the Performance phenomenon from different angles which complement one another. (Sabine, S. \&Michael F., 2017).The Same study analyzed the three aforementioned perspectives on Performance and demonstrated how for example current changes in the nature of work such as the focus on continuous learning and proactivity, increase in team work, improved technology and trend very globalization have an impact on the performance concept. The study asserted that the integration of the three perspectives on the performance is highly needed, particularly it asserted that linking the individual differences and the situational factors result in high individual performance which is relevant for organizational goals.

This theory is relevant to our study given that it helped us to understand the logic behind Human Resources practices in different banks aiming to motivate staff members toward achieving both individual and bank performances.

\subsection{Organizational Performance}

According to Patrick, M. et al, (2017) financial performance refers to the degree to which financial objectives are being or have been accomplished. It is the process of measuring the results of a firm's policies and operations in monetary terms. It is used to measure firms' overall health over a given period of time.

Performance of organizations is measured regarding firm's ability to achieve their specific organizational objectives, Performance refers to ability to operate efficiently, profitably, survive, grow and react to environmental opportunities and threats .Return on Equity (ROE), Return on Assets (ROA) and Net Interest Margin are often used to proxy the measurement of Financial Performance of the banks.(Umaru,2017)

\subsection{Empirical Review}

A recent study conducted by Abbas Umar (2019) across manufacturing firms in Nigeria revealed a significant positive relationship between financial control mechanisms and firms 'profitability performance. It further recommended 
that manufacturing firms should continuously improve on their application of financial control techniques. It was recommended that manufacturing firms should continuously improve on their application financial control techniques through the selection of suitable and consistent control mechanisms.

A study conducted by (Joseph Mwaura ,2013) analyzing the effect of Financial Planning and financial Performance in automobile industry in Kenya, confirmed a strong relationship between Financial Planning and Financial Performance of the firms, it further states that the success of any business depends on the manner financial plans are formulated.

Studying Financial Performance of the Public Sector Rathiranee Yogendrarajah, (2011) conducted a study to analyze how financial control of Jaffna municipal council (India) affects its organizational performance, the study suggested that effective tools of financial control management could have a positive impact on the Jaffna Municipal council, the study suggested in addition that an effective financial control leads to better organizational performance, finally the research proved that there is a positive relationship between financial control and organizational performance. The study recommended that public organizations should take attention in the financial control to manage public service activities effectively.

A research conducted by Sahabi Ibrahim and Gordon Diibuzie (2017) confirmed a positive relationship between internal controls and financial performance of health institutions in Ghana. The researchers went further to analyze the impact of each internal control system components and highlighted that all the five internal control Variables have positive relationship with the bank performance, however out of the five elements only three have significant relationship i.e. Control activity, Internal audit and Monitoring; while the two remaining i.e. Control environment, Information and Communication have shown an insignificant effect on financial performance of the banks in Nigeria. Husain Umar and Mohammed Umar Dikko studying on effect of internal control systems on financial performance of banks in Nigeria, (2018) confirm that internal control has a significant relationship with bank performance because customers would like to patronize banks that have Control, Security and safeguard their deposits.

Another study conducted by Sentil Kumaran 2015, tried to establish responsibilities of Financial Control teams in both small and large organizations, according to the same study Financial Control teams are responsible for ensuring that all accounting entries are correctly made and that there is supporting documentation for validating each entry. In small companies, the financial controller would be directly responsible for managing cash, accounts payable, payroll disbursement and accounts reconciliation. In large companies, there may be a number of control units looking into different aspects of the firm's finances. He further classifies major roles of financial control teams in organizations as under: Secure internal controls (The financial controllers are responsible for establishing the procedures for securing the internal controls of the company. Under their supervision, every invoice will have to be reviewed, aging accounts looked into, and debts managed. They will have to lay down the compliance rules, make sure that the rules are adhered to and also changed from time to time. Furthermore, they will have to set up a system for maintaining records and ensure that the records are easily available for those who need to read them), Collect and Record Data (The financial control team will have to work closely with the tax accountants and internal auditors. Auditors require all kinds of data for completing their work, and the financial controllers will have to make sure that the data is available. Tax accountants also need updated accounting books and information to judge what the tax liabilities of the company are going to be and how they can save tax. The financial controllers will have to explain different accounting entries to them so that the tax accountants can file accurate statements.) Analyze Data (Financial control does not end at merely maintaining proper records. Since they are the ones who have access to large volumes of data and they also understand it well, financial controllers have to be skilled at financial analysis and providing a perspective on what the numbers mean. Before taking an important business decision, the chief financial officer or the chief executive officer might call the financial controller and ask his opinion on whether there is enough financing to go ahead with a project. Financial controllers are in a position to assess risk, analyze efficiency and take a view on the policy decisions made by senior management. Their opinions are often sought for long-term financial planning as well), Do reporting (Financial Controllers forms a huge part of the financial controller's role. Balance sheets, budgets, cash flow statements, asset statements and financial projections cannot be released until the financial controllers have substantiated them. In small companies, the controller would even be responsible for all banking activities and might have to negotiate lines of credit with financial institutions and purchase agreements with vendors. The financial controller also has to ensure that the numbers which appear in the financial statements are accurate.) In the same spirit the same study asserts that financial control affects every part of the company. Therefore, the tasks of financial controllers are virtually unlimited. Their jobs involve a lot of coordination with other departments. They will have to hold regular meetings with other divisions to explain new policies, the need for regular data sharing, and the implications of the procedures they plan to lay down for the company. They will also have to stay in touch with government and regulatory policies so that they can implement them as and when they are changed.

Trying to establish an effect of control Activity on financial management in Kenya Public Sector (Mirangine County); J. Wachira, et al (2014) highlighted weakness in implementing financial controls, their study used a population of 30 accounting and administrative staff members, it concluded that the prudential use of financial resources in Mirangine Sub County government was not appropriate. The study further confirmed a significant positive relationship between control activities and financial management.

In his study Robert N. Githiaya (2017). Analyzing reasons behind bank failures and closures in Kenya in 2015 and 2016 i.e. .Dubai Bank, Chase Bank Imperial Bank in Kenya, among the advanced reasons behind the failure and closure the study allegedly suggested: poor performance, Insider lending, weak corporate governance practices, weakness in regulatory and supervisory systems, poor risk management strategies, lack of internal controls and conflict of interest ,however the study did not stress the role of allegedly weak financial control system impact in the matter. 
El-Nafabi (2008) trying to establish the role of public sector audit and financial control systems in safeguarding public funds in South Sudan. His study highlighted some factors which encourage financial corruption in the public sector. It asserted that financial control systems and internal controls in many of public sector units were weak and ineffective, among other factors the study mentioned shortage or lack of qualified and trained accountants, absence of internal auditing, deficiencies in the accounting system in most public firms, accounting system being done manually at the national level being behind the weak system.

Daniel Mulingye Nthenge and Japhet Ringera, (2017), conducted a research, trying to establish a relationship between Financial Management Practices and Financial Performance of the Small and Medium industries in Kiambu town (Kenya), using three variables of the Finance Management Practice, i.e. working Capital Management, Investment decisions and Financing decisions; the research resulted into the following conclusion that a combined effect of Financial Management practices (working Capital Management, Investment decisions and finally Financing decisions has a moderate effect to the financial performance of small and medium firms in Kenya.

Innocent, (2017) conducted a study on Financial Control and Financial Sustainability of health Centers in Rwanda, The study targeted 14 health centers, and it surveyed 71 respondents it reached a conclusion that among many factors contributing to financial instability of the health centers in Rwanda i.e. Lower prices fixed by health insurances, a good number of poor patients who cannot afford the price of the health services, lack of internal control and procedures, poor budgeting and responsibilities assignment, weak procedures and financial control practices; the study concluded that 52\% variations in financial sustainability are explained by Financial Control Practices. There for confirming a positive correlation between Financial Control System and the Financial Sustainability of the health Centers.

Going through different literature review we observed that a lot was largely documented regarding the importance of upholding an internal control system for the success of the companies in general and the banks in particular. However, on Rwanda based cases there is still a significant gap to fill regarding the effect of the Financial Control System on the Performance of the Banks, we have scholars confirming that an internal control system has a positive impact on the financial performance of the banks. We couldn't find any study demonstrating how a well-designed and operating Financial Control System can drive financial performance of the banks in Rwanda. On other hand as mentioned in previous sections of this paper a weak internal control system in general and the financial control particularly can be a source of the bank failure. Specifically, the efforts of the research were to shade the light upon the effect of a well-organized financial control system on the performance of the banks in Rwanda in particular.

\section{Methodology}

A descriptive survey design was conducted on 240 employees drawn from 540 employees of 14 commercial banks in Rwanda. Both stratification and simple random sampling techniques were applied to ensure better coverage of the population, greater accuracy and equity in the representation from the various departments. The sample constitution was as indicated in Table 1 below:

\begin{tabular}{|c|c|}
\hline & Number of Employees \\
\hline Corporate Business Banking-Department & 60 \\
\hline Retail Business Banking & 35 \\
\hline Credit Risk department & 45 \\
\hline Financial Control-Department & 20 \\
\hline Operations Department & 80 \\
\hline Total sample size & 240 \\
\hline
\end{tabular}

Table 1: Sample Constitution

The formula for stratified sampling is as follows (Cohen 2003).

$$
n=\frac{N}{1+N e^{2}}
$$

Where

$$
\begin{aligned}
& \mathrm{n}=\text { Sample Size } \\
& \mathrm{N}=\text { Number of Population } \\
& \mathrm{e}=\text { Significant Error Term }(0.05)
\end{aligned}
$$

The sample size out of the target population of 240 respondents in the 2 selected banks will be as follows: -

$$
\begin{aligned}
n=\frac{540}{1+(540 * 0.05)^{2}} & \\
& \\
& =\frac{540}{2.25} \\
& =240 \text { Employees (Sample Size) }
\end{aligned}
$$

A closed ended questionnaire was used in collecting the primary data while secondary data was obtained through a review of the relevant bank reports for the period 2015-2019. The data was processed and analyzed for both descriptive and inferential statistics using Statistical Package for Social Sciences (SPSS). 


\section{Results and Findings}

\subsection{Gender of the Employees}

Results on the gender of respondents as indicate in Table 2, indicates that 183 respondents were male representing $76.3 \%$ and 57 females representing $23.8 \%$, of the total 240 respondents that were used in the study. This is an indication that the ratio of male respondents was higher than that of the female respondents used in the study

\begin{tabular}{|c|c|c|}
\hline \multirow{2}{*}{ Gender of the respondents } & \multicolumn{2}{|c|}{ Number of Respondents } \\
\cline { 2 - 3 } & Frequency (f) & $\begin{array}{c}\text { Percentage of Male and female } \\
\text { respondents (\%) }\end{array}$ \\
\hline Male & 183 & $76.25 \%$ \\
\hline Female & 57 & $23.75 \%$ \\
\hline Total & 240 & $100.0 \%$ \\
\hline
\end{tabular}

Table 2: Gender of the Employees

\subsection{Department Employees Work}

The respondents were required to indicate the department they work in. Table 3 indicates the summary of the employees in various departments in the bank.

Table 3 indicates that out of the total 240 respondents, 60 respondents representing 25\% belong to the Corporate Business Banking, 35 respondents, representing 15\% belong to the Retail Banking department, 55 respondents, representing 23\% belong to the Credit Risk Management department and 20 respondents representing 8\% belong to the Financial Department; while 70 Respondents representing 29\% are from Operations departments

\begin{tabular}{|c|c|c|}
\hline Department & Frequency & Percentage \\
\hline Corporates Business Banking & 60 & $25 \%$ \\
\hline Retail Banking Business & 35 & $15 \%$ \\
\hline Credit Risk Management & 55 & $23 \%$ \\
\hline Finance Control & 20 & $8 \%$ \\
\hline Operations & 70 & $29 \%$ \\
\hline Total & 240 & $100 \%$ \\
\hline
\end{tabular}

Table 3: Employees Numbers Arranged by Departments

\subsection{Number of Years Worked in the Bank}

The respondents were required to indicate the number of years they have worked in the bank. Table 4 indicates the summary of the employee's responses. The findings in Table 4 indicate that out of the 240 employees 40 (16.7\%) have worked with the companies below 1 year, 98(40.83\%) have worked with the companies between 1 and 3 years, $87(36.25 \%)$ have worked with the companies between 4 and 6 years, while $13(5.4 \%)$ have worked with the company from 7 years and above.

\begin{tabular}{|c|c|c|}
\hline & \multicolumn{2}{|c|}{ Number of Respondents } \\
\hline Number of years & Frequency & Percentage \\
\hline Below 1 year & 40 & $16.7 \%$ \\
\hline $1-3$ years & 98 & $40.83 \%$ \\
\hline $4-6$ years & 87 & $36.25 \%$ \\
\hline 7 n Years & 15 & $6.25 \%$ \\
\hline Total & 240 & $100.0 \%$ \\
\hline
\end{tabular}

Table 4: Number of Years Worked in the Bank

\subsection{Terms of Employment}

The respondents were required to indicate their terms of employment, permanent, temporary or part-time. Table 12 indicates the summary of the employment terms of the employees working in the companies. The findings in Table 5 indicate that out of the 240 employees all the employees $240(100.0 \%)$ are employed on permanent basis.

\begin{tabular}{|c|c|c|}
\hline & \multicolumn{2}{|c|}{ Number of Respondents } \\
\hline Terms of employment & Frequency & Percentage \\
\hline Permanent & 240 & $100.0 \%$ \\
\hline Temporary & 0 & $0 \%$ \\
\hline Part time & 0 & $0 \%$ \\
\hline
\end{tabular}

Table 5: Terms of Employment 


\subsection{Academic Qualification}

The respondents were required to indicate their level of education either diploma/ certificate, bachelor's degree, master's degree. They were also allowed to specify any other level they may have acquired, in questionnaire that was presented to them. Table 6 gives a summary of the level of education of the employees working in the bank under study that participated in filling the questionnaires. Table 6 indicates that out of the 240 respondents, $23(9.6 \%)$ have a certificate/diploma, 158 (65.8\%) have a bachelor's degree and 59 (24.6\%) have a Master's degree. No respondent indicated to be PHD degree.

\begin{tabular}{|c|c|c|}
\hline \multirow{2}{*}{ Academic Qualification } & \multicolumn{2}{|c|}{ Number of Respondents } \\
\cline { 2 - 3 } & Frequency & Percent \\
\hline Certificate/Diploma & 23 & $9.58 \%$ \\
\hline Bachelor's degree & 158 & $65.8 \%$ \\
\hline Master's degree & 59 & $24.6 \%$ \\
\hline Total & 240 & $100.0 \%$ \\
\hline
\end{tabular}

Table 6: Academic Qualification of the Respondents

\subsection{The Respondent's Perception on the Activities of Financial Control System on the Performance of the Bank}

The area of Finance that the researcher focused on include Finance Control team's contribution in Formulation of the bank performance Standards, Disclosing and Discussing reasons behind Standard Performance deviation, Management of flows of resources, Management of Operational Risk.

\subsection{Formulation and Management of the Bank Performance Standards}

The respondents were required to indicate their perception on the Finance Contribution in formulation of the bank financial performance standards. Table 7 indicates that the highest mean was 2.85 while the lowest was 2.28 , this means that respondents tend to agree in all the variables under study apart from one element that were covered under this variable. The results show that the respondents tend to agree that Finance Control unit drives both strategic plan and the budget of the bank this is presented with a mean of $(\bar{X}=2.84)$, and standard deviation of ( $\mathrm{S}=0.67)$.

The respondents tend to agree that Finance unit participates in definition of the performance standards for the bank. This is presented with a mean of ( $\bar{X}=2.85)$, and standard deviation of (S=0.72). The respondents tend to agree that Finance Control monitors Performance Realization. This is presented with a mean of $(\bar{X}=2.68)$, and standard deviation of $(\mathrm{S}=0.91)$.

The respondents tend to agree though with disparity that Finance team monitors and approve budget execution. This is presented with a mean of $(\bar{X}=2.28)$, and standard deviation of ( $\mathrm{S}=0.71)$.

The respondents tend to agree Finance team reports and discuss with the management and the board of Directors about Performance Deviations. This is presented with a mean of $(\bar{X}=2.83)$, and standard deviation of ( $\mathrm{S}=0.79)$.

The respondents tend to agree Finance team Propose corrective measures to the poor performance of the bank. This is presented with a mean of ( $\bar{X}=2.65)$, and standard deviation of (S=0.88).

The overall mean for Formulation and Monitoring of the financial performance standards of the bank was ( $\bar{X}$ $=2.69$ ), indicating that respondents tend to agree with the Finance role to formulate and monitor financial performance standards a resulting standard deviation of $0.32<0.5$ indicates homogeneity in the groups.

\begin{tabular}{|c|c|c|}
\hline $\begin{array}{c}\text { Finance Control participates in definition of both strategic plan and the budget } \\
\text { of the bank }\end{array}$ & Mean & Std. Deviation \\
\hline $\begin{array}{c}\text { Finance control unit participates in definition of the performance standards for } \\
\text { the bank. }\end{array}$ & 2.85 & 0.67 \\
\hline $\begin{array}{c}\text { Finance Control monitors Performance Realization } \\
\text { Finance team monitors and approve budget execution }\end{array}$ & 2.68 & 0.72 \\
\hline $\begin{array}{c}\text { Finance team reports and discuss with the management and the board of } \\
\text { Directors about Performance Deviations }\end{array}$ & 2.28 & 0.93 \\
\hline $\begin{array}{c}\text { Finance team Propose corrective measures to the poor performance of the } \\
\text { bank. }\end{array}$ & 2.65 & 0.79 \\
\hline Overall Mean & 2.69 & 0.88 \\
\hline
\end{tabular}

Table 7: Formulation and Monitoring of the Financial Performance Standards of the Bank

\subsection{Management of Flows of Resources}

The respondents were required to indicate their perception on the role that finance control teams plays as far as flow of resources is concerned. The findings are as indicated in Table 8.

Respondent are of the view that Finance team plays a significant role in defining Procurement 
The respondents tend to agree though with disparity with a mean value of 2.62 and a standard deviation of .78 When asked if Finance Control unit ensures that all the bank expenditures are reviewed and approved by the authorized persons referring to a pre-approved budget before any cash flow. The respondents tend to agree though with disparity with a mean of 2.63 and standard deviation of 0.71 .

The respondents were asked to indicate whether Finance teams do a proper reconciliation of the bank general ledgers including cash and bank balances accounts. They tended to agree with a mean of 3.05 and standard deviation of 0.62 .

Respondent were asked to provide an opinion on whether Finance Control manage the bank liquidity, respect the minimum reserve requirements, and avoid excessive idle balances. They respondents tend to agree with a mean value of 2.93 though in disparity with a standard deviation value of 0.68 indicating heterogeneity. The disparity is majorly a result that in many banks management of liquidity is a separate role handled by the treasury department.

Respondent were asked to provide an opinion on whether Finance Control unit maintains an up-to-date bank asset register. Respondents tend to agree with a mean value of 3.0 though in disparity with a standard deviation value of 0.68 indicating heterogeneity.

When asked to provide an opinion on whether the bank fixed assets are recoded before they are moved to any new location. Respondent agreed with a mean value of 2.87 with a standard deviation of 0.75

On the question to know if the procurement and disposal of bank assets procedure is strictly followed the respondent agreed with a mean value of 3.29 with a standard deviation of 0.52

Respondent were asked to give an opinion on whether Finance control maintain a vendor master list, which allows the bank to deal with the best contractors: they responded with a mean of 3.15 and a S.D of 0.81

Finally, respondent was asked to provide an opinion on whether Finance Unit maintains a capital tracker, revealing capital position for a timely Capital Call when it may be needed, respondent responded with a mean value of 3.75 with a S.D of 0.52

The overall mean for Management of Flow of resources was 2.93 interpreted as tend to agree and standard deviation of 0.23 indicating homogeneity in the response of the respondents.

\subsection{Managing Flow of Resources}

Respondent were asked to provide their opinion about the role played by financial control teams regarding flow of the bank resources, questionnaire was covering the role of finance teams in defining the bank procurement policy and procedure, execution and monitoring of the budget, liquidity management, reconciliation of the bank general ledgers, safeguarding the bank assets, Capital monitoring and Reporting.

Respondent agreed with a mean value of 2.93 and a standard variation of 0.23 indicating homogeneity in the response of the respondents. Table 8 summarizes the respondent opinions.

\begin{tabular}{|c|c|c|}
\hline & Mean & Std. Deviation \\
\hline $\begin{array}{c}\text { Finance team plays a significant role in defining Procurement procedures } \\
\text { of the bank. }\end{array}$ & 2.62 & 0.78 \\
\hline $\begin{array}{c}\text { Finance Control unit ensures that all the bank expenditures are reviewed } \\
\text { and approved by the authorized persons referring to a pre-approved } \\
\text { budget before any cash flow. }\end{array}$ & 2.63 & 0.71 \\
\hline $\begin{array}{l}\text { Finance teams prepare a proper reconciliation of the bank general } \\
\text { ledgers including cash and bank balances accounts. }\end{array}$ & 3.05 & 0.62 \\
\hline $\begin{array}{l}\text { Finance Control manage the bank liquidity, respect the minimum reserve } \\
\text { requirements, and avoid excessive idle balances. }\end{array}$ & 2.93 & 0.68 \\
\hline The bank maintains an up-to-date bank asset register. & 3.00 & 0.68 \\
\hline $\begin{array}{l}\text { The bank fixed assets are recoded before they are moved to any new } \\
\text { location. }\end{array}$ & 2.87 & 0.75 \\
\hline $\begin{array}{l}\text { The procurement and disposal of bank assets procedure is strictly } \\
\text { followed. }\end{array}$ & 3.29 & 0.52 \\
\hline Any procurement and disposal of in the bank assets are not influenced. & 2.76 & 0.81 \\
\hline $\begin{array}{l}\text { Finance control maintain a vendor master list, which allows the bank to } \\
\text { deal with the best contractors }\end{array}$ & 3.15 & 0.81 \\
\hline $\begin{array}{c}\text { The Bank maintain a capital tracker, revealing capital position for a } \\
\text { timely Capital Call when it may be needed. }\end{array}$ & 3.75 & 0.52 \\
\hline Overall Mean & 2.93 & 0.23 \\
\hline
\end{tabular}

Table 8: Managing Flow of Resource

\subsection{Prevention and Management of the Operational Risks}

Basel Committee suggests that Operation Risk in Banks can results from inadequate processes, People and Systems, the respondents were required to indicate their perception on the role of Finance in Preventing and managing the Operation risk in the bank. The findings are as indicated in Table 9. 
The respondents were asked to express their opinion on the role of Finance Control on Bank Processes when asked if Finance team respect policies and procedures of the banks before processing payments. The respondents tend to agree in their response though in disparity with a mean value of 3.49 and standard deviation of 0.50 .

People actions and re-actions in banks can be source of operational risk. Respondent were asked to give an opinion on whether finance teams prepares and post accurately transactions in systems they tended to agree with a mean of 3.55 and standard deviation of 0.55 .

The System quality assurance resulted into a mean of 3.33 with a standard deviation of 0.59

The overall mean for Operational Risk management was 3.45 interpreted as tend to agree and standard deviation of 0.31 indicating homogeneity in the response of the respondents.

\begin{tabular}{|c|c|c|}
\hline & Mean & Std. Deviation \\
\hline $\begin{array}{l}\text { Processes: Finance team respects policies and procedures of the banks } \\
\text { before processing payments }\end{array}$ & 3.49 & 0.50 \\
\hline $\begin{array}{c}\text { People-Accurately Finance teams Prepares and Post Transactions in } \\
\text { System }\end{array}$ & 3.55 & 0.55 \\
\hline $\begin{array}{c}\text { System: Finance Control monitors and assures quality of the Core } \\
\text { banking systems (Generated revenue and accrued liabilities are } \\
\text { periodically assessed and reported) }\end{array}$ & 3.33 & 0.59 \\
\hline Overall Mean & 3.45 & 0.31 \\
\hline
\end{tabular}

Table 9: Prevention and Management of the Operational Risks

\section{Discussion}

he main objective of this study was to examine the effect of Financial Control System on financial performance of commercial Banks in Rwanda; The area of Finance that the researcher focused on include the role of finance control unit on formulation and monitoring of the financial performance standards of the bank, management of flows of resources, prevention and management of the operational risks.

\section{Findings in Summary}

We scanned the literature to get different scholars points of views on the matter, different research findings from the scholars are included in empirical review section of this study. We couldn't find any study rejecting the role of finance control system on the financial performance of the firms especially of the banks, on the other hand we discovered that different studies confirmed a positive relationship of the Financial Control System on the Financial Performance of the firms, Coming back on the Rwanda Base cases, a lot was documented regarding the effect of the internal control system on the performance of the banks, however we couldn't find any study analyzing the effect of the financial control system on the financial Performance of the banks, the main reason of this study was to bridge the aforementioned gap . It was revealed that Finance Control system has a significant role on the financial performance of the banks. The role of Finance Control teams in Formulation and Management of the Bank Performance Standards has got a mean $(\bar{X}=2.69)$, and a standard deviation of $(\mathrm{S}=0.32)$, Management of flows of Resources has got a mean $(\bar{X}=2.93)$, and a standard deviation of $(\mathrm{S}=0.23)$; while the prevention and management of operational Risk gets a mean $((\bar{X}=3.45)$, and a standard deviation of $(S=0.31)$. The study concluded that the banks in Rwanda carry out Financial Control activities on a regular basis, they fully consider the financial control function as an integral part of the financial management; and this has resulted into a positive relationship between financial control system and Financial Performance of the banks.

\section{Recommendations}

- Given a significant effect of the Financial Control system on the performance of the banks hence the stability of the banking sector, the study recommends that commercial banks in Rwanda enhance the finance function, and provide the function with more qualified staff members and all the required resources.

- The Rwanda Bank Association, the Central bank supervision department and the banks should organize periodical forums discussing about the issues facing Financial Controls functions in the banks and come up with some proposals to adopt for a more banking sector stability.

- Our study tried to cover one area of the Financial Management, more researches are recommended to be made, especially on Rwanda based cases covering other functions of the financial Management i.e. Financial Planning and its effect on the financial stability of the banks, Investment Decisions and their effects on the financial performance of the banks and finally the Financing Decisions and their effect on the bank stability.

\section{References}

i. Block, S.B and Geoffrey, A.H. (2008) Foundation of Financial Management.

ii. Bett \& Memba (2017). The Impact of Internal Control Design on Banks, Ability to Investigate Staff Fraud, and Life Style and Fraud Detection in Nigeria, International Journal of Research in Economics \& Social Sciences, 2 (2), 32-43

iii. Bett \& Memba (2017). Internal control, accountability and corporate governance: Medieval and modern Britain compared. Accounting, Auditing \& Accountability Journal, 7: 1052 - 
iv. COSO (2018). Internal Control Integrated Framework, Report of the committee of sponsoring organizations of Trade way Commission, Jersey: American Institute of CPA Casio W.F. (1998) Applied Psychology in Human Resource Management, $5^{\text {th }}$ Ed. Prentice Hall, International UK

v. Daniel, M. N. and Japhet, R. (2017). "Effect of Financial Management Practices on Financial Performance of Small and Medium enterprises in Kiambu town, Kenya", American Based Research Journal, Vol-6-Issue-1 Jan-2017 ISSN (2304-7151).

vi. Eduard, A. O. (2015). "Development of Financial Control System in the company in Crisis"

vii. El-Nafbi, H.M. (2008). The role of public sector audit and financial control systems in safeguarding public funds in Sudan, Journal of Economics\& Administration.

viii. Fung, L., (2012). Financial Management. London School of Economics and Political Science (LSE), London. London Scholl of Economics and Political Science

ix. Goldon, D. (2017) "The Impact of Internal Control Systems on Financial Performance: The Case of Health Institutions in Upper west Region of Ghana".

x. Husaini, U., \& Mohammed (2018). Effect of Internal Control on Performance of the banks in Nigeria

xi. Innocent, M. (2017). Financial Controls and Financial Sustainability of Health Centers in Rwanda, A case study of health centers governed by convention in Rusizi District.

xii. John, W., Solomon, N., Juma, W. (2014). Effect of Financial Controls on Financial Management in Kenya's public Sector: A case of National government departments in Mirangine Sub-County, Nyandarua County

xiii. Joseph, M. (2013), The Effect of Financial Planning on Financial Performance of automobile firms in Kenya

xiv. Joshi, P. Jawahar A., Wayne G., Bremser (2003): “Corporate Budget Planning, Control and Performance Evaluation in Bahrain", Managerial Auditing Journal, Vol.18

xv. Ostman, L. (2009). Towards a general theory of financial control for organizations. Working Paper Series in business administration, Vol.9.

xvi. Patrick, M.C, Julius Robert, O., Gregory, S.N. (2017). Effect of Public Financial Management Practices on Performance in Kericho County Government, Kenya: A critical Review

xvii. Financial Control and Its Impact on Organizational Performance-An Empirical Study Of J/ Municipal Council, Competency Building Strategies in Business and Technology (2011), Vol. II, Sri Sai Ram Institute of Management Studies, Chennai.

xviii. Rekha Khandelwal (2019). Understanding a Bank's operational and Business Risks, Retrieved October, 2019 from https://marketrealist.com/

xix. Robert N. Gathaiya (2017). "Analysis of issues affecting collapsed banks in Kenya from the year 2015 to 2016"

xx. Sabine, S. Michael. (2017), Performance Concept and Performance Theory, Retrieved May, 15, 2020 from https://www.researchgate.net/publication 291062476

xxi. Sahabi, I., Gordon, D., (2017). The internal control Systems on Financial Performance, The case of Health Institutions in Upper west region of Ghana

xxii. Sentil Kumaran (2015). Essential Roles of Financial Control team, Retrieved January, 11, 2020, from https://www.invensis.net

xxiii. Umar Muhammed et al, (2017). Effect of internal control on commercial banks of Nigeria, a proposed framework.

xxiv. Umaru, H. (2018), Effect of International Control on Performance of Commercial banks in Nigeria: a proposed framework 